\title{
KEPEMILIKAN RELATIF (AL-MILKIYAH AL-MUQAYYADAH) PRIVAT DAN PUBLIK DALAM EKONOMI ISLAM
}

\author{
Sarmiana Batubara \\ Program Studi Perbankan Syariah STAI Barumun Raya \\ J1. Ki Hajar Dewantara No. 66 B Sibuhuan, Padang Lawas, Kab. Kab. Padang Lawas Utara \\ e-mail: syarmabatubara@yahoo.com
}

\begin{abstract}
This paper discusses how ownership in the Islamic economy, especially about relative ownership (almilkiyah al-muqayyadah) from the perspectives of the Qur'an and hadith. This is a library research. The conclusions of this discussion are: 1) The concept of ownership is really regulated in the Qur'an and Hadith where many verses of Al-qur'an and Hadith that discuss about the relative ownership of both private and public ownership. 2) The possessions of human beings are not his essential property. Human ownership is only a substitute and a representative of God over the earth. It is an obligation for humans to infaon their possessions in order to fulfill God's right to bim, as well as the obligation of a person to provide for his family and to spend another's fortune if permitted. Islam recognizes the existence of individual ownership, but it is not an absolute possession, that is ownership which is limited by certain rules. Islam has established the permissibility of each individual to own property in private. 3) Islam not only recognizes individual ownership that is essentially concerned only with private rights, but also recognizes ownership in general so that it can be exploited by the people, such as water, grass and fire.
\end{abstract}

Kata kunci: kepemilikan relatif, harta, individu

\section{PENDAHULUAN}

H arta pada hakikatnya merujuk pada alam. Menurut pandangan Alquran, itu adalah nikmat Allah, alat-alat provisi (perlengkapan), kesenangan dan kebanggaan. Harta bukanlah sesuatu yang buruk. Alquran menyatakan bahwa ia adalah sesuatu yang baik (khair) dan juga sebagai alat yang membantu kehidupan manusia. Alquran banyak menekankan untuk mempergunakan kekayaan yang dimiliki dalam hal-hal yang baik.

Pernyataan bahwa harta itu adalah sebagai kebaikan, memungkinkan kita untuk menyatakan bahwa kehidupan tanpa kekayaan itu tidak baik. Dalam
Hadis Rasulullah juga sangat menekankan pada umatnya untuk mencari harta yang halal dan menafkahkan hartanya pada jalan yang benar. Harta dan anak digambarkan Alquran sebagai sumber kekuatan dan kehormatan.

Dalam beberapa ayat Alquran menyifati kepemilikan kekayaan pada manusia. Penyifatan seperti ini bukan berarti manusia adalah pemilik hakiki. Allah sebagai pemilik hakiki dari kekayaan ini memberikan mandat kepada manusia untuk menjadi khalifah-Nya yang diberi karunia-Nya sebagai pemilik sementara harta itu, dan diberi wewenang untuk mengatur harta benda itu dengan sebaik-baiknya. 


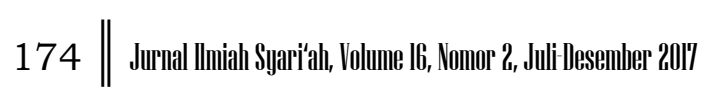

Dalam memperoleh harta, manusia harus tetap pada syari'at, Rasulullah Saw sangat fokus dengan persoalan yang menyangkut dengan kepemilikan harta kekayaan. Beliau sangat memperhatikan dari mana seorang memperoleh harta. Beliaulah yang merumuskan formula yang sangat terkenal "min ayna laka haadza?" (darimana kamu dapat ini semua?). kemudian Umar bin Khathab dengan tegas mempraktikkan formula ini untuk para gubernur dan para pejabat di jajaran pemerintahannya.

Dalam makalah ini penulis akan menyajikan makalah yang membahas tentang wawasan Alquran dan Sunnah tentang kepemilikan khususnya kepemilikan relatif (al-milkiyah al-muqayyadah) baik kepemilikan privat (pribadi) maupun kepemilikan publik (umum).

\section{KEPEMILIKAN RELATIF (AL-MILKIYAH AL-MUQAYYDAH)}

Secara etimologi, kata milik berasal dari bahasa arab al-milk yang berarti penguasaan terhadap sesuatu. Al-milk juga berarti sesuatu yang dimiliki (harta). (Mas'adi, 2002: 53) Milik juga merupakan hubungan seseorang dengan sesuatu harta yang diakui oleh syara'. Secara terminologi defenisi al-milk adalah (Haroen, 2000: 31):

$$
\text { إختصاص با الشيء يمنع الغير منه ويمكن صاحبه من :31 : }
$$

"Pengkhususan seseorang terhadap suatu benda yang memungkinnya untuk bertindak hukum terhadap benda itu (sesuai dengan keinginannya) selama tidak ada halangan syara'."
Artinya benda yang dikhususkan kepada seseorang itu sepenuhnya berada dalam penguasaannya, sehingga orang lain tidak boleh bertindak dan memanfaatkannya.

Sesungguhnya hanya Allah yang menciptakan segala sesuatu yang ada di alam semesta, semua yang ada di alam ini adalah milik Allah. Firman Allah dalam surat al-A'raf ayat 128 .

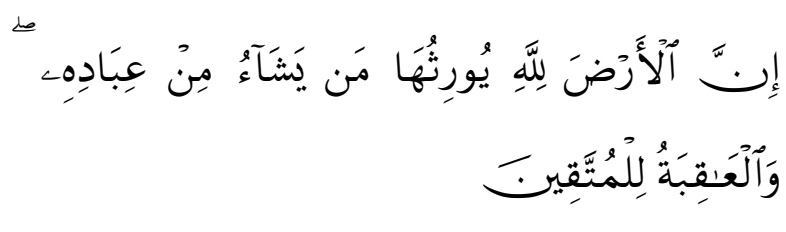

"Sesungguhnya bumi (ini) kepunyaan Allah; dipusakakan-Nya kepada siapa yang dihendaki-Nya dari hamba-hamba-Nya. dan kesudahan yang baik adalah bagi orangorang yang bertakwa". (Q.S. al-A'raf [7]: 128)

Ayat ini menceritakan kisah Fir'aun yang merasa sangat berkuasa atas bumi ini, ayat ini merupakan nasihat Musa kepada kaumnya yang telah cemas, mereka mesti memperkuat benteng iman mereka kepada Allah, memperteguh kepercayaan. Meskipun Fir'aun telah mengatakan bahwa ia sangat berkuasa melakukan apa yang dia ingini terhadap Bani Isra'il, namun yang mempunyai bumi ini yang sebenarnya bukanlah Fir'aun, tetapi Allah. Di atas kekuasaan Fir'aun ada kekuasaan Allah dan kesudahan yang baik adalah bagi orangorang yang bertakwa. (Hamka, 1985: 40)

Kesimpulan yang disampaikan oleh ayat ini adalah bahwa Fir'aun berkuasa atas izin Allah juga. Yang memberikan kekuasaan itu mampu untuk mencabutnya. Karena itu, jika manusia berupaya sambil meminta pertolongan Allah dan tabah menghadapi segala tantangan dan 
rintangan, niscaya akan dianugerahi kekuasaan.

Allah menciptakan bumi dengan segala isinya, kemudian Allah ciptakan manusia. Setelah Allah menciptakan hamparan bumi dan segala isinya, Allah mengajak kepada umat manusia untuk mengambil bagian mereka. Setiap manusia yang hidup di atas bumi, mempunyai hak yang tidak bisa diganggu dan dihalangi oleh orang lain, hak itu mencukupi segala kebutuhan pokok hidupnya. (Sami' Al-Misri, 2006: 27)

Dengan demikian manusia harus berusaha agar mendapatkan harta, yakni berusaha dengan jalan yang baik dan benar yaitu sesuai dengan syariat Islam, karena sebaik-baiknya apa yang akan dipakai untuk kebutuhan sehari-sehari diperoleh dari hasil usaha sendiri. Rasulullah SAW bersabda (Nashiruddin, 2007: 294):

$$
\begin{aligned}
& \text { عن عائشة قالت, قال رسول الله صلى الله عليه وسلم : } \\
& \text { إن أطيب ما اكل الرجل من كسبه و إن ولده من كسبه. } \\
& \text { (رواه إبن ماجهه) }
\end{aligned}
$$

"Dari Aisyah RA. Ia berkata: Rasulullah SAW bersabda, sesungguhnya hal yang terbaik yang dimakan oleh seseorang adalah apa yang Ia dapat dari hasil usahanya sendiri, dan sungguh anaknya adalah hasil usahanya". (HR. Ibnu Majah).

Semua harta kekayaan yang ada di bumi merupakan hak milik Allah, kepemilikan manusia atas benda hanya kepemilikam yang datang kemudian dan tidak bisa menghapus kepemilikan Allah yang abadi.

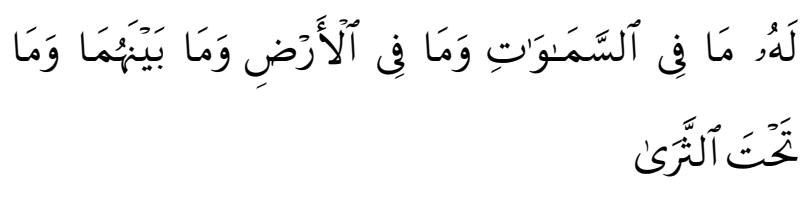

"Kepunyaan-Nya-lah semua yang ada di langit, semua yang di bumi, semua yang di antara keduanya dan semua yang di bawah tanah".

Pemberdayaan manusia atas segala fasilitas kehidupan, bukan berarti dapat menafikan kepemilikan Allah yang hakiki atau aset-aset tersebut. Dan juga tidak bisa dipahami bahwa kepemilikan atas harta benda berpindah dari Allah menjadi milik manusia. Kepemilikan manusia hanyalah kepemilikan untuk menikmati memberdayakan harta kekayaan yang ada, bukan sebagai pemilik yang hakiki. Manusia hanya bisa memiliki kemanfaatan dan fasilitas yang ada. seperti mempunyai tanah untuk dimanfaatkan sebagai tempat tinggal, sebagai lahan pertanian, ataupun sebagai ladang bisnis. Kepemilikan yang ada hanya sebatas mengambil manfaat dan tidak bisa menghilangkan kepemilikan Allah yang hakiki. Yakni dengan menafkahkan sebagian harta yang dimiliki.

Allah berfirman dalam surat AlHadid ayat 7:

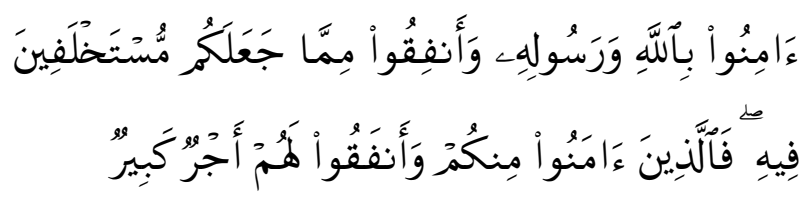

"Berimanlah kamu kepada Allah dan rasulNya dan nafkahkanlah sebagian dari hartamu yang Allah telah menjadikan kamu menguasainya. Maka orang-orang yang beriman di antara kamu dan menafkahkan (sebagian) dari hartanya 


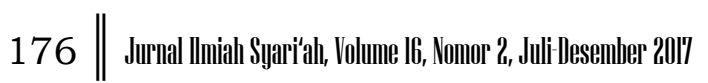

memperoleh pahala yang besar". (Q.S. AlHadid [57]: 7)

Yang dimaksud dengan menguasai di sini ialah penguasaan yang bukan secara mutlak. Hak milik pada hakikatnya adalah pada Allah. Manusia menafkahkan hartanya itu haruslah menurut hukumhukum yang Telah disyariatkan Allah. Karena itu tidaklah boleh kikir dan boros.

Di dalam Kitab Tafsir Al-Maraghi dijelaskan penafsiran ayat tersebut di atas, yakni:

1. بالهواله و رسوله keesaan Allah, dan benarkanlah RasulNya tentang apa yang dia datangkan dari Tuhan kamu.

2. وأنفقوا مما جعلكم مستخلفين فيه dan belanjakanlah harta yang ada padamu, yang sebenarnya merupakan pinjaman itu, karena harta tersebut pernah pula berada pada tangan umat sebelum kamu, kemudian beralih kepadamu. Dan gunakanlah harta itu dalam ketaatan kepada Allah, kalau tidak maka Allah akan menghisab kamu atas harta tersebut dengan hisab yang berat. Alangkah baiknya perkataan:

$$
\begin{aligned}
& \text { * وما المال والأهلون إلا ودائع }
\end{aligned}
$$

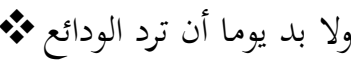

Harta dan keluarga, tak lain hanyalah titipan belaka, pada suatu hari titipantitipan itu pasti dikembalikan".

3. maka orangorang yang beriman kepada Allah dan membenarkan rasul-Nya diantara kamu, disamping membelanjakan di jalan Allah harta yang Allah pindahkan kepada mereka dari generasi sebelumnya, mereka akan mendapatkan pahala yang besar disisi Tuhan mereka.
Di sana mereka akan melihat kemuliaan dan pahala yang tidak pernah dilihat oleh mata, tak pernah didengar oleh telinga, dan tidak pernah terlintas dalam hati manusia seseorang pun. (Al-Maraghi, 1989: 287-288)

Al-Zamakhsyari menafsirkan bahwa harta kekayaan yang berada dalam kekuasaan manusia, sesungguhnya adalah milik Allah semata yang telah menciptakan dan menghadirkannya untuk manusia. Allah memberikan kesempatan dan kekuasaan kepada manusia untuk memanfaatkan dan memberdayakan segala kekayaan alam semesta demi kelangsungan hidup di dunia. Harta yang dikuasai manusia bukanlah merupakan milik hakiki baginya, kepemilikan manusia hanya merupakan pengganti dan wakil Allah atas bumi. Merupakan sebuah kewajiban bagi manusia untuk melakukan infak atas harta benda yang dimiliki guna memenuhi hak Allah atasnya, seperti halnya kewajiban bagi seseorang untuk memberikan nafkah kepada keluarganya dan menafkahkan harta orang lain jika diizinkan. (Sami' Al-Misri, 2006: 28)

\section{KEPEMILIKAN PRIBADI (PRIVATE PROPERTY)}

Islam mengakui adanya kepemilikan individu, namun bukanlah sebuah kepemilikan yang mutlak, kepemilikan yang dibatasi dengan kaidah-kaidah tertentu. Sebagai agama yang sesuai dengan fitrah manusia, Islam telah menetapkan adanya kebolehan setiap individu untuk memiliki harta benda secara pribadi. Allah berfirman dalam surat An-Nisa ayat 32: 


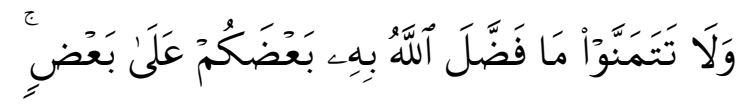

"Dan janganlah kamu iri hati terhadap apa yang dikaruniakan Allah kepada sebahagian kamu lebih banyak dari sebahagian yang lain". (Q.S. An-Nisa [4]: 32)

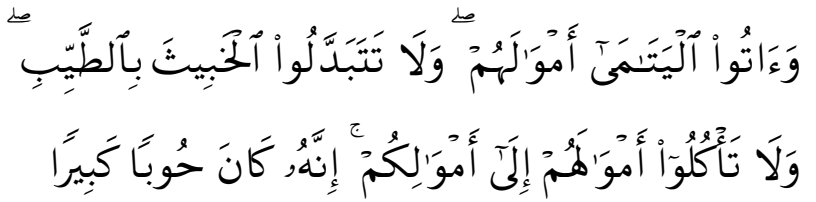

"Dan berikanlah kepada anak-anak yatim (yang sudah balig) harta mereka, jangan kamu menukar yang baik dengan yang buruk dan jangan kamu makan harta mereka bersama hartamu. Sesungguhnya tindakan-tindakan (menukar dan memakan) itu, adalah dosa yang besar". (Q.S. An Nisa' [4]: 2 )

Penafsiran ayat di atas dalam kitab kitab Tafsir Al-Maraghi, yakni:

1. واتواليتمى اموالهم , yang dimaksud dengan memberikan harta kepada anak-anak yatim ialah menjadikannya khusus untuk mereka, dan tidak boleh sedikit pun untuk dimakan dengan cara yang batil (tidak sah). Artinya wahai wali dan penerima wasiat harta anak yatim, peliharalah harta anak yatim itu, janganlah kamu memperlakukannya dengan cara yang tidak baik, dan serahkanlah harta mereka ketika kamu telah merasa bahwa kedewasaan telah tumbuh dalam diri mereka, sebab anak yatim adalah orang lemah, tidak mampu memelihara hartanya dan mempertahankannya.

2. janganlah kamu mengganti harta halal, yaitu hartamu sendiri yang kamu hasilkan dari jerih payahmu sendiri berkat kemurahan
Allah, lalu kamu menggantikannya dengan harta haram yaitu harta anak yatim yang dititipkan kepadamu.

3. yang dimaksud dengan memakan ialah semua penggunaan yang menghabiskan harta. Sesungguhnya disini hanya disebutkan istilah memakan, karena sebagian besar penggunaan harta benda itu untuk tujuan makan. Dan kata ila (إلى) bermakna ma'al atau beserta. Arti keseluruhan ayat ialah "janganlah kalian memakan harta anak-anak yatim dengan mencampurkan dan menggabungkan di antara keduanya.

4. sesungguhnya memakan harta milik anak yatim termasuk perbuatan dosa besar. (Al-Maraghi, 1989: 323)

Islam mengharamkan kepemilikan harta menggunakannya untuk membuat kerusakan di muka bumi dan membahayakan manusia, karena tatanan Islam mengajarkan prinsip laa dharara wa la dhirara (tidak membahayakan diri dan membahayakan orang lain). Islam juga melarang umatnya menginvestasikan harta pribadinya pada sektor yang menyebabkan kerusakan moral. Firman Allah dalam surat Al-Baqarah ayat 188:

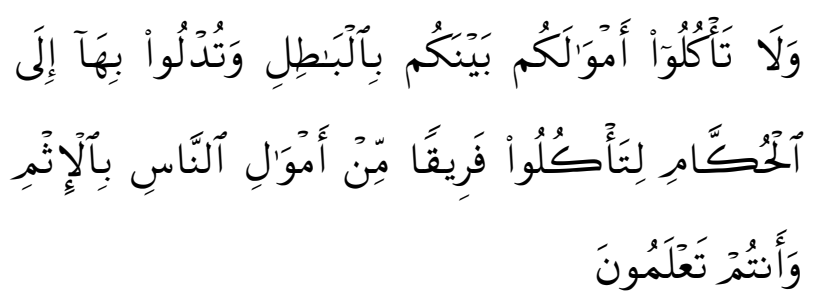

"Dan janganlah sebahagian kamu memakan harta sebahagian yang lain di antara kamu dengan jalan yang batil dan (janganlah) kamu membawa (urusan) harta 


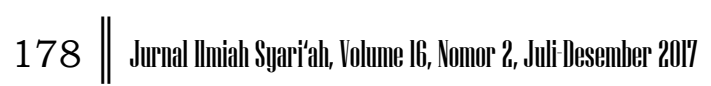

itu kepada hakim, supaya kamu dapat memakan sebahagian daripada harta benda orang lain itu dengan (jalan berbuat) dosa, padahal kamu Mengetahui". (Q.S. alBaqarah [2]: 188)

Dalam kitab Tafsir Al-Misbah ayat ini dijelaskan, janganlah kamu memakan harta sebagian kamu antara kamu, yakni janganlah memperoleh dan menggunakannya. Harta yang dimiliki oleh si A hari ini, dapat menjadi milik si B esok. Harta seharusnya memiliki fungsi sosial, sehingga sebagian diantara apa yang dimiliki si A seharusnya dimiliki pula oleh si B, baik melalui zakat maupun sedekah. Pengembangan harta tidak dapat terjadi kecuali dengan interaksi antara manusia dengan manusia lain, dalam bentuk pertukaran dan bantu-membantu. Makna-makna inilah yang antara lain dikandung dalam penggunaan kata antara kamu (بينكم) dalam firmannya yang memulai uraian menyangkut perolehan harta. Kata antara juga mengisyaratkan bahwa interaksi dalam perolehan harta terjadi antara dua pihak. Harta seakanakan berada ditengah dan kedua pihak berada pada posisi ujung yang berhadapan. Keuntungan atau kerugian dari interaksi itu, tidak terlalu ditarik jauh oleh masing-masing, sehingga salah satu pihak merugi, sedangkan pihak lain mendapatkan keuntungan, sehingga bila demikian harta tidak berada ditengah atau antara, dan kedudukan kedua belah pihak tidak lagi seimbang. Perolehan tidak seimbang adalah batil, dan yang batil adalah segala sesuatu yang tidak hak, tidak dibenarkan oleh hukum, serta tidak sejalan dengan tuntunan Ilahi walaupun dilakukan atas dasar kerlaan yang berinteraksi. (Shihab, 2002: 288)
Dengan demikian menurut penulis Ayat diatas dapat dimaknai, janganlah sebagian kamu mengambil harta orang dan menguasainya tanpa hak, dan jangan pula menyerahkan urusan harta kepada hakim yang berwenang memutuskan perkara bukan untuk tujuan memperoleh hak kalian, tetapi untuk mengambil hak orang lain dengan melakukan dosa, dan dalam keadaan mengetahui bahwa kalian sebenarnya tidak berhak. Tidak semua hak milik pribadi dilindungi oleh Islam. Islam tidak melindungi kepemilikan harta benda yang diperoleh dengan jalan haram dan melindungi hak milik yang diperoleh dengan jalan yang halal. Artinya harta yang dimiliki seharusnya diperoleh dari jalan yang halal, Rasulullah pernah bersabda (Al-Albani, 2007: 24):

$$
\begin{aligned}
& \text { عن أبي هريرة رضي الله عنه, عن النبي صلى الله عليه وسلم }
\end{aligned}
$$

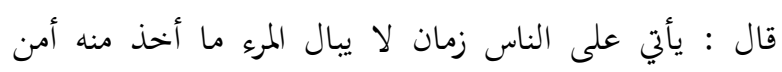

$$
\begin{aligned}
& \text { الحلال أم من الحرام (رواه بخارى). }
\end{aligned}
$$

"Dari Abu Hurairah RA, dari Nabi SAW, beliau bersabda, "Akan datang kepada manusia suatu masa yang mana sesorang tidak peduli darimana ia mendapatkan harta, apakah dari yang halal atau yang haram". (HR. Bukhari).

Harta benda yang dimiliki, yang ditipkan Allah kepada manusia haruslah dipergunakan dengan baik, untuk menambah ketaatan dalam beribadah serta meningkat keimanan kepada Allah. Jangan karena harta benda menjadikan seseorang lalai akan perintah Allah. Firman Allah dalam surat Al-Fath ayat 11:

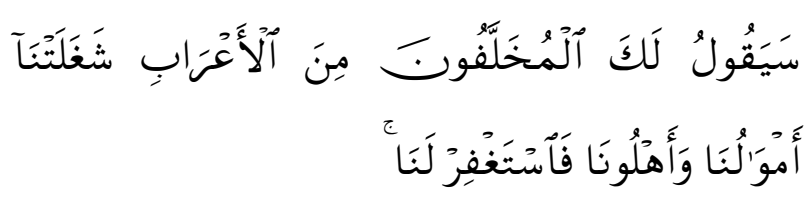


"Orang-orang Badwi yang tertinggal (Tidak turut ke Hudaibiyah) akan mengatakan: "Harta dan keluarga kami Telah merintangi kami, Maka mohonkanlah ampunan untuk kami" (Q.S. al-Fath [48]: 11)

Bahwa sebelum Nabi berangkat menuju Makkah untuk berumrah, beliau mengajak kelompok-kelompok al-'Arab yakni masyarakat penduduk gunung (badui).yang ketika itu telah memeluk Islam untuk berangkat bersama beliau melaksanakan umrah, tetapi mayoritas mereka tidak menyambut baik ajakan itu. Mereka disibukkan oleh upaya memelihara harta yakni ternak dan keluarga yaitu anak dan isteri mereka. Jika mereka ikut menurut mereka harta mereka akan hilang dan keluarga mereka akan terlantar. (Shihab, 2002: 188) Mereka lupa jika harta dan anak hanyalah cobaan.

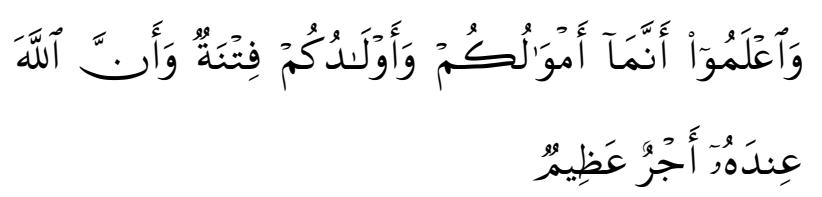

"Dan Ketahuilah, bahwa hartamu dan anak-anakmu itu hanyalah sebagai cobaan dan Sesungguhnya di sisi Allah-lah pahala yang besar". (Q.S. al-Anfal [8]: 28)

Atinya harta yang dititipkan kepada mereka membuat mereka sibuk dan lalai dalam menjalankan ibadah kepada Allah. Padahal dalam surat lain Allah memerintahkan kepada hamba-Nya yang memilki harta benda agar berangkat ke medan jihad dengan harta yang mereka miliki.

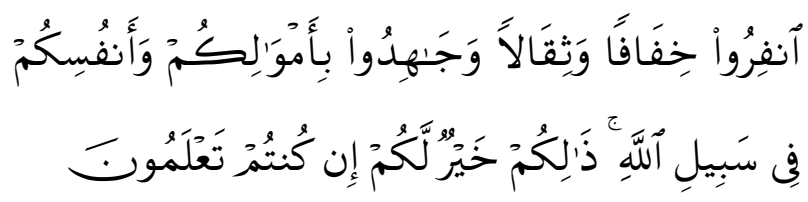

"Berangkatlah kamu baik dalam keadaan merasa ringan maupun berat, dan berjihadlah kamu dengan harta dan dirimu di jalan Allah. yang demikian itu adalah lebih baik bagimu, jika kamu Mengetahui". (Q.S. at-Ataubah [9]: 41)

Dalam ayat tersebut kata harta lebih didahulukan dari pada jiwa/diri (انفسكمم) untuk menekankan perlunya menyumbangkan harta benda dalam situasi perang. (Shihab, 2002: 602)

Islam mewajibkan atas seluruh manusia untuk menjaga hak miliknya. Rasulullah SAW bersabda: (Haroen, 2000: 76)

$$
\text { هى رسول الله عن اضاعة المال (رواه بخارى و مسلم ) }
$$

"Rasulullah SAW melarang membuangbuang harta". (HR. Bukhori dan Muslim).

Bahkan orang-orang yang terbunuh karena gigih mempertahankan hartanya dan membelanya hak miliknya, maka ia digolongkan sebagai orang yang mati syahid. (Al-Albani, 2007: 481)

$$
\begin{aligned}
& \text { عن سعيد ابن زيد بن عمر وبن ثقيل, عن النبي صلى الله عليه } \\
& \text { وسلم قال : من قتل دون ماله فهو شهيد (رواه إبن ماجهة) } \\
& \text { "Dari Sa'id ibnu Zaid ibnu Umar dan } \\
& \text { Ibnu Tsaqil, dari Rasulullah SAW }
\end{aligned}
$$




\section{KEPEMILIKAN UMUM (PUBLIC PROPERTY)}

Islam tidak hanya mengakui pemilikan secara perseorangan yang pada hakikatnya hanya mementingkan hak pribadi, tetapi juga mengakui pemilikan secara umum sehingga bisa dimanfaatkan oleh orang banyak. Tujuannya adalah agar bahan pokok yang ada tidak dimanfaatkan sebagian orang dengan sewenang-wenang yang menyebabkan terlantarnya orang banyak.

Dalam surat A-Rahman ayat 10 Allah berfirman:

$$
\text { وَأَلأَرْضَضَوَضَعَهَا لِلَأَنَامِ }
$$

"Dan Allah Telah meratakan bumi untuk makhluk (Nya)". (Q.S. ar-Rahman [55]:

10)

Di samping keadaaan langit yang diatur Allah sedemikian rupa, bumi diletakaan-Nya yakni dihamparkan-Nya untuk kenyamanan semua makhluk hidup yang menghuninya. Bukan hanya sekedar menghamparkan, tetapi juga menyiapkan bahan pangan dan kenyamanan hidup makhluk, karena di dalamnya yakni bumi yang dihamparkanNya itu ada buah-buahan dan pepohonan dan juga biji-bijian yang berkulit atau berdaun atau bunga-bunga yang harum aromanya. (Shihab, 2002: 501)

Nabi menetapkan bahan pokok tersebut adalah air, ladang rerumputan, dan api. Beliau bersabda (Baqi dan Fawa', t,th.: 773):

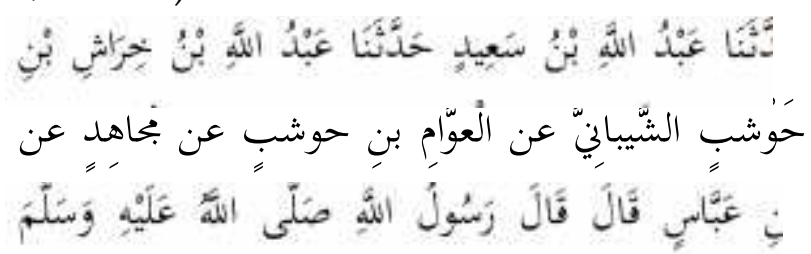

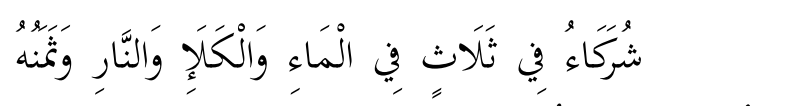

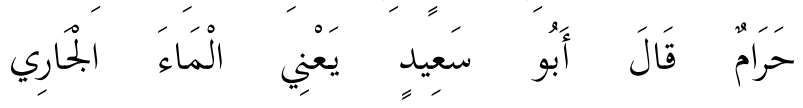

"Telah menceritakan kepada kami Abdullah bin Sa'id berkata, telah menceritakan kepada kami Abdullah bin Khirasy bin Hausyab Asy Syaibani dari Al Awwam bin Hausyab dari Mujahid dari Ibnu Abbas ia berkata, "Rasulullah shallallahu 'alaihi wasallam bersabda: "Kaum muslimin berserikat dalam tiga hal; air, rumput dan api. Dan harganya adalah haram." Abu Sa'id berkata, "Yang dimaksud adalah air yang mengalir". (HR. Ibnu Majah).

Yang dimaksud air dalam Hadis ini adalah adalah air sungai, mata air milik umum, dan air lainnya yang diperoleh tanpa jerih payah orang-orang tertentu. Dengan kata lain mata air yang diperoleh dengan cara menggali tanah seperti sumur atau kolam tidak termasuk air milik umum.

Yang dimaksud dengan kala' menurut Imam Kurthubi ialah apa yang tumbuh di tanah tidak bertuan. Tidak ada seorang pun yang berhak atas hasil tanah tidak bertuan ini dengan melarang orang lain mengambil hasilnya.

Menurut sebagian ulama, yang dimaksud dengan api adalah batu yang memercikkan api. Tidak seorang pun berhak melarang orang lain mengambil api dari gesekan batu itu. Ulama lain berpendapat, bahwa yang dimaksud api dalam Hadis Nabi ialah sarana perapian yang didapatkan tanpa ada usaha dari seseorang. Misalnya kayu bakar di hutan belukar atau di padang pasir. Kayu ini tidak ada pemiliknya dan tumbuh lewat tiupan angin tanpa adanya pemeliharaan secara khusus oleh manusia. (Qardhawi, 1997: 91) 
Rasulullah SAW bersabda (AsSuyuthi, 2006: 222):

$$
\text { وسلم نبي عن بئهال عن إياس أن رسول الله صلى الله عليه }
$$

"Dari Abu Minhal, dari Ilyas, bahwa Rasullullah SAW melarang untuk menjual air".

Diharamkan menjual kelebihan air yang melebihi kebutuhan, Tirmidzi mengatakan "Ini yang diamalkan oleh kalangan mayoritas ulama" menurut AsySyaukani, Hadis tersebut menunjukkan diharamkan menjual kelebihan air jika melebihi kebutuhan pemiliknya. Air untuk minum ataupun untuk keperluan lain, baik untuk kebutuhan binatang ataupun tanaman. Menurut sebagian ulama, adapun orang yang telah mengambil air lalu telah diletakkannya dalam satu wadah, maka air itu menjadi miliknya. Dan apabila air itu telah menjadi miliknya, maka bolehlah ia menjualnya. (As-Suyuthi, 2006: 223)

Alquran banyak menekankan untuk mempergunakan kekayaan dalam hal-hal yang baik, yang disebut dengan infak. Implikasinya adalah bahwa mencari penghasilan, memiliki kekayaan bukan saja suatu hal yang baik, namun itu adalah hal yang sangat esensial agar orang bisa berinfak. Sebab sangat tidak mungkin seseorang akan berinfak jika dia tidak memiliki harta benda. (Ahmad, 2003: 53) Ulama sepakat, tempat ibadah, madrasah, jalan, wakaf yang diperuntukkan demi kebaikan umat masuk dalam kepemilikan publik. (Al-Misri, 2006: 71) Sebagaimana di dalam Alquran dinyatakan bahwa menafkahkan sebagian dari harta yang dimiliki dalam hal yang baik merupakan perintah Allah.

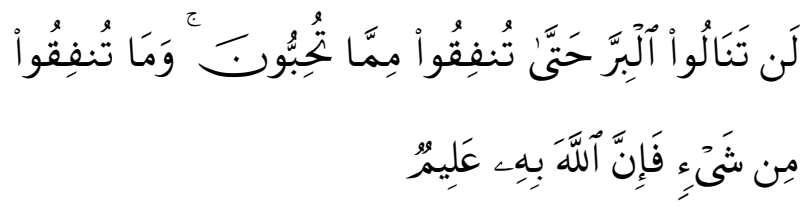

"Kamu sekali-kali tidak sampai kepada kebajikan (yang sempurna), sebelum kamu menafkahkan sehahagian harta yang kamu cintai. dan apa saja yang kamu nafkahkan Maka Sesungguhnya Allah mengetahuinya". (Q.S. Ali-Imran [3]: 92)

Hadis Rasulullah tentang kepemilikan umum yang salah satunya adalah wakaf yaitu tentang sedekah Jariyah yang ditafsirkan ulama sedekah jariyah dalam Hadis tersebut adalah wakaf. (Hajjaj, 1998: 281)

\section{عن أبي هريرة رضي الله عنه, ان رسول الله صلى اله عليه وسلم

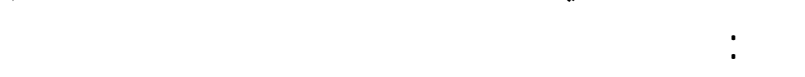

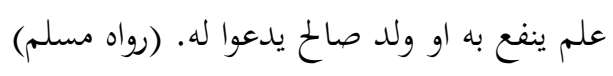

"Dari Abu Hurairah, Rasulullah SAW bersabda: Jika meninggal anak Adam terlepaslah semua amal ibadahnya kecuali tiga hal, sedekah Jariyah, atau ilmuyang diajarkan dan anak sholeh yang mendokannya". (HR. Muslim).

Ghanimah dan fai' juga merupakan harta milik umum, yang mana harta tersebut dipergunakan untuk kemaslahatan umum terutama anak yatim, orang-orang miskin dan ibnu sabil. Sebagaimana firman Allah dalam surat Al-anfal ayat 41:

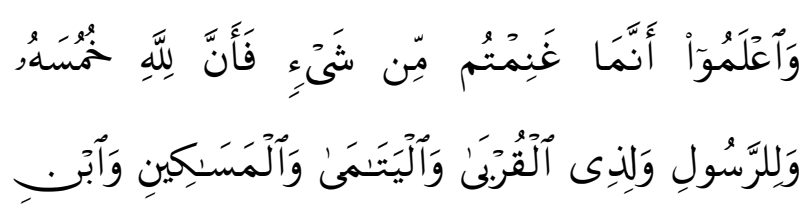




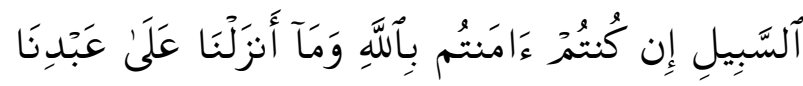

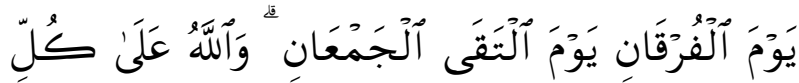
شَنْ قَدِيرِ

"Ketahuilah, Sesungguhnya apa saja yang dapat kamu peroleh sebagai rampasan perang, Maka Sesungguhnya seperlima untuk Allah, rasul, kerabat rasul, anakanak yatim, orang-orang miskin dan ibnussabil jika kamu beriman kepada Allah dan kepada apa yang kami turunkan kepada hamba kami (Muhammad) di hari Furqaan, yaitu di hari bertemunya dua pasukan. dan Allah Maha Kuasa atas segala sesuatu". (Q.S. al-Anfal [8]: 41)

Dalam menafkahkan harta untuk kepentingan umum maka yang diberikan bukanlah barang yang tidak layak (buruk), melainkan barang yang baik agar orang lain dapat memanfaaatkan benda tersebut dengan baik pula. Sebagaimana firman Allah dalam surat Al-Baqarah 267:

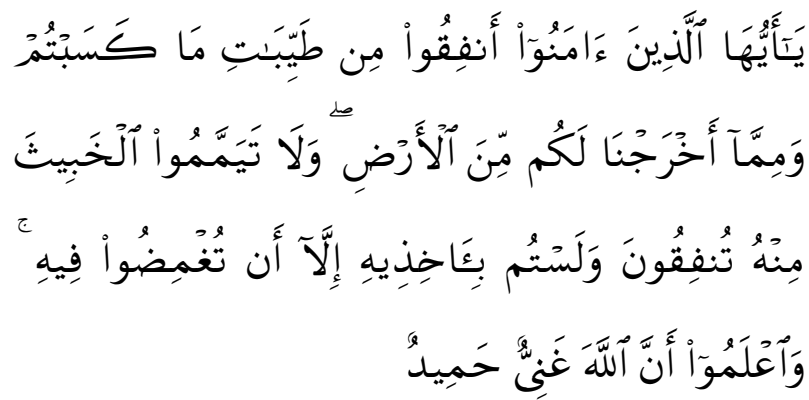

"Hai orang-orang yang beriman, nafkahkanlah (di jalan Allah) sebagian dari hasil usahamu yang baik-baik dan sebagian dari apa yang kami keluarkan dari bumi untuk kamu, dan janganlah kamu memilih yang buruk-buruk lalu kamu menafkahkan daripadanya, padahal kamu sendiri tidak mau mengambilnya melainkan dengan memincingkan mata terhadapnya. dan Ketahuilah, bahwa Allah Maha Kaya lagi
Maha Terpuji". (Q.S. Al-Baqarah [2]: 267)

Allah menitipkan rezeki berbedabeda terhadap hamba-Nya. Tidak semua manusia diberi rezeki yang dapat mencukupi kehidupan sehari-harinya, namun ada juga yang diberi rezeki yang berlebih oleh Allah. Semua harta yang dititipkan Allah, baik banyak atau sedikit adalah milik Allah. Dengan demikian manusia yang dilebihkan Allah dalam rezeki seharusnya memberikan sebagian rezekinya kepada yang lain, agar samasama dapat menikmati rezeki itu.

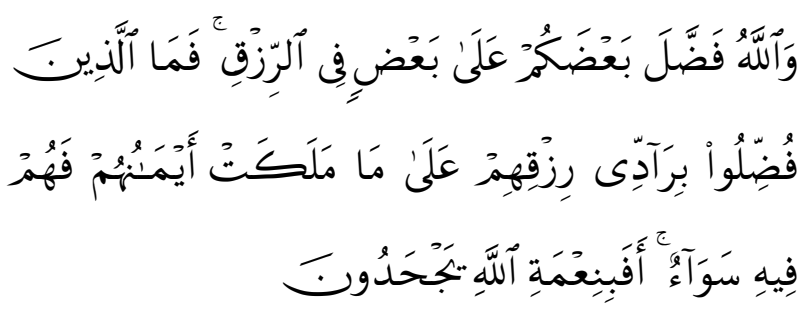

Dan Allah melebihkan sebahagian kamu dari sebagian yang lain dalam hal rezki, tetapi orang-orang yang dilebihkan (rezkinya itu) tidak mau memberikan rezki mereka kepada budak-budak yang mereka miliki, agar mereka sama (merasakan) rezki itu. Maka Mengapa mereka mengingkari nikmat Allah. (Q.S. An-Nahl [8]: 71)

Dalam Tafsir Al-Misbah dijelaskan, ayat ini menyatakan: dan Allah maha kuasa lagi bijaksana itu melebihkan sebagian kamu wahai manusia atas sebagian yang lain dalam hal rezeki, walaupun boleh jadi yang memiliki kelebihan itu lemah fisik, atau berusia muda lagi tidak berpengatahuan, lalu kendati Allah menganugerahkan rezeki itu dan membagi-bagikannya sesuai hikmah kebijaksanaannya, namun tidaklah orang-orang yang dilebihkan rezekinya itu mau memberikan separuh rezeki yang 
mereka peroleh dari Allah itu kepada budak-budak yang mereka miliki, agar mereka sama merasakan rezeki itu. Ada juga ulama yang memahami ayat ini dalam arti anjuran kepada pemilik harta agar menyerahkan sebagian dari kelebihan rezeki yang mereka peroleh kepada kaum lemah, yakni para budakbudak dan fakir miskin. Seakan-akan ayat ini menyatakan bahwa Allah telah menganugerahkan kepada kamu kelebihan dibanding dengan yang lain, maka adalah sewajarnya kamu menyalurkan kelebihan itu kepada orang-orang yang butuh sehingga kamu sama seperti mereka dalam pemenuhan kebutuhan hidup. Bukankah kelebihan yang terdapat dalam genggaman tangan kamu itu adalah nikmat Allah, dan seharusnya nikmat itu kamu sebarluaskan? Apakah kamu enggan menyebarluaskannya karena kamu mengingkari nikmatnya? (Shihab, 2002: 288)

Menurut analisis penulis, konsep ekonomi Islam dalam hal kepemilikan relatif mempunyai karakteristik untuk mendialektikkan nilai-nilai materialisme dan spritualisme. Memberikan pendidikan dan pengarahan kepada manusia untuk menciptakan sebuah komunitas kehidupan masyarakat yang dibangun atas nilai tolong menolong dan kasih sayang antar individu, bukan hanya sekedar membentuk sebuah masyarakat yang hanya berorientasi materi.

\section{PENUTUP}

Dari pemaparan di atas dapat diambil kesimpulan yakni:

1. Konsep kepemilikan benar-benar diatur dalam Alquran dan Hadis, artinya banyak ayat Alquran maupun Hadis Rasulullah yang membicarakan kepemilikan relatif baik kepemilikan pribadi maupun umum.

2. Harta yang dikuasai manusia bukanlah merupakan milik hakiki baginya, kepemilikan manusia hanya merupakan pengganti dan wakil Allah atas bumi. Merupakan sebuah kewajiban bagi manusia untuk melakukan infak atas harta benda yang dimiliki guna memenuhi hak Allah atasnya, seperti halnya kewajiban bagi seseorang untuk memberikan nafkah kepada keluarganya dan menafkahkan harta orang lain jika diizinkan.

3. Islam mengakui adanya kepemilikan individu, namun bukanlah sebuah kepemilikan yang mutlak, kepemilikan yang dibatasi dengan kaidah-kaidah tertentu. Islam telah menetapkan adanya kebolehan setiap individu untuk memiliki harta benda secara pribadi.

Islam tidak hanya mengakui pemilikan secara perseorangan yang pada hakikatnya hanya mementingkan hak pribadi, tetapi juga mengakui pemilikan secara umum sehingga bisa dimanfaatkan oleh orang banyak. Diantaranya adalah air, rumput, dan api.

\section{DAFTAR KEPUSTAKAAN}

Ahmad, Mustaq. 2003. Etika Bisnis dalam Islam. Jakarta: Pustaka Al-Kautsar.

Al-Albani, Muhammad Nashiruddin. 2006. Shahih Sunan Tirmidzi. diterjemahkan oleh Fachrurazi. Jakarta: Pustaka Azzam. 
2007. Ringkasan Shahih Bukhari. diterjemahkan oleh M. Faisal. Jakarta: Pustaka Azzam.

2007. Shahih Sunan Ibnu Majah. diterjemahkan oleh Ahmad Taufiq Abdurrahman. Jakarta: Pustaka Azzam.

Al-Maraghi, Ahmad Musthafa. 1989. Tafsir Al-Maraghi Juz 27. diterjemahkan oleh Bahrun Abu Bakar. Semarang: Toha Putra.

1989. Tafsir Al-Maraghi Juz 4. diterjemahkan oleh Bahrun Abu Bakar. Semarang: Toha Putra.

Al-Misri, Abdul Sami'. 2006. Pilar-Pilar Ekonomi Islam. diterjemahkan oleh Dinyauddin Djuwaini. Jakarta: Pustaka Pelajar.

As-Suyuthi, Muhammad bin Kamal Khalid. 2006. Kumpulan Hadis yang Disepakati 4 Imam. Jakarta: Pustaka Azzam.

At-Tarmidzi, Imam Hafiz Abi Isa Muhammad ibnu 'Isa bin Surah.
T.th. Sunan At-Tirmidzi Juz III. Semarang: Toha Putra.

Fawa', Muhammad dan 'Abdul Baqi. T.th. Sunan Ibnu MajahJuz II. Qohiroh: Warorul Hadis.

Hamka. 1985. Tafsir Al-Azhar Juz IX. Jakarta: Pustaka Panjimas

Haroen, Nasrun. 2000. Figh Muamalah. Jakarta: Gaya Media Pratama.

Ibnu Hajjaj, Imam Abi Husein Muslim. 1998. Terjemahan Hadis Shahih Muslim Juz II. Jakarta: Pustaka Al-husna.

Mas'adi, Ghufron A.. 2002. Fiqh Muamalah Kontekstual. Jakarta: Raja Grapindo Persada.

Qardhawi, Yusuf. 1997. Norma dan Etika Ekonomi Islam. Jakarta: Gema Insani.

Shihab, M. Quraish. 2002. Tafsir Al-Misbah Volume 1. Jakarta: Lentera Hati.

2002. Tafsir Al-Misbah Volume 13. Jakarta: Lentera Hati 